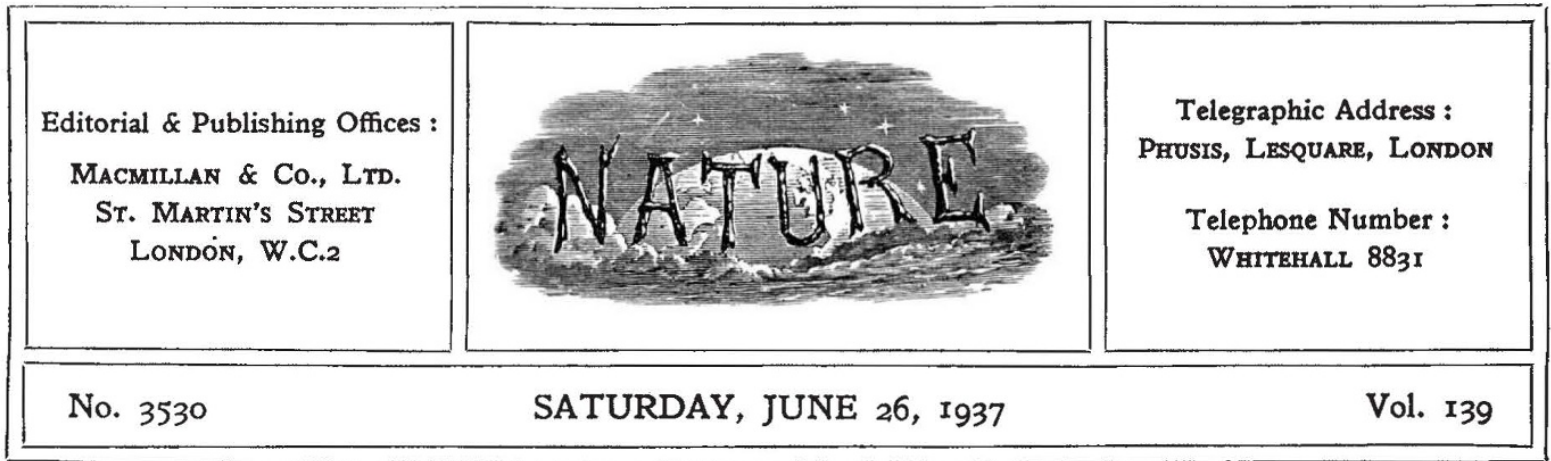

\title{
Native Policy in the Empire
}

$\mathrm{L}$ ORD NOEL-BUXTON, in bringing forward a motion in the House of Lords on June 9 that native policy in the Empire should be considered in the present session of the Imperial Conference, raised a question of wide and farreaching implication, involving the status and well-being of vast populations of backward peoples who, whatever their present grade of civilization and condition of tutelage, are nevertheless members of the Empire, and, presumably, will hand on that privilege with its rights and duties to their descendants.

The wording of the motion was as follows:

That this House, in view of the divergences in native policy now developing in different parts of his Majesty's Dominions and Dependencies, believes that the time has arrived for the Imperial Conference to formulate such policy in broad outline, with a view to protecting the rights and promoting the advancement of all races of the Empire, whatever may be their religion and colour, and that such policy should be based upon the principle of trusteeship.

It was, by leave, withdrawn ; but its exact and comprehensive phraseology will not be forgotten when, as is inevitable, the question is raised again and further discussed.

The motion forced not one, but several cards. In the debate which followed, discussion tended decidedly to criticize, defend or extenuate existing policies in native administration, rather than to discuss the merits of the substantive proposal. This is not entirely to be regretted. It afforded an opportunity for expression of opinion on the principle of 'trusteeship', upon which the motion had asked for a direction from their Lordships.
An important exchange of views emerged, which might have been stifled at its inception by an official intimation that at this late date it was impossible to entertain the proposal.

In supporting his motion, Lord Noel-Buxton had little difficulty in making out a case. It is probable that most will agree that the Imperial Conference affords the best, perhaps the only, effective machinery for the full and free discussion of the position, which is not only fast becoming anomalous, but also may-indeed in Africa inevitably will-become dangerous, unless handled with foresight and statesmanship. It is not without significance that Mr. Ormsby-Gore, in his review of the affairs of the Colonial Office during recent years before the Imperial Conference on May 31, stated that he considered that the main political problem which confronts the Colonial Office is still "the relationship between natives and nonnatives, both European and Asiatic, in many territories, following the growth of education and the awakening of political consciousness". It cannot be doubted that a colonial administrator of his experience must also have had at the back of his mind the problem as it is manifested in instances which were not under review. In a matter of so delicate a character as this question has become under the provisions of the Statute of Westminster, the initiative demands a strong force of informed opinion as a stimulus to any action which will ensure discussion on an Empire-wide basis.

The anomalies which were adduced by Lord Noel-Buxton in support of his argument might be multiplied manifold; but it was sufficient for him to contrast the position in West Africa and 
in New Guinea with the conditions of the pass system and under-colour bar legislation to demonstrate the gulf that lies between what are, broadly speaking, two schools of thought in approach to the problem of the backward races of the Empire. On one side, as in West Africa, the native is afforded full opportunity for educational and economic development, as well as a measure of co-operation in the administration of affairs. In New Guinea, among peoples who a brief time past were head-hunters, living in the stone age, education in the purpose of administrative measures and some participation in their working have been productive of even an enthusiasm for paying taxes. On the other hand, in South Africa, where racial feelings run high, the prevailing policy is one of repression and domination.

On the main principle, so far as it affects the natives of territories directly under the control of the British Parliament, their Lordships' expression of opinion is virtually unanimously on the side of the benefit of the native being the paramount interest of administration. A word of caution was put forward by the Marquess of Lothian, who in sympathy with the patent difficulties of the Colonial Office, stressed the obligation to white settler as well as native; but the feeling of the House was such as to justify the view that the aim of the Government as stated by the Marquess of Dufferin, Under Secretary of the Colonial Office, "to govern the indigenous races in their own interests and with a view to their elevation in the scale of civilization", will not be allowed, in this 'place' at least, an interpretation which would permit, for example, the natives of the South African Protectorates to be exposed to such regulation as it has been proposed to apply to the indigenous inhabitants of the mandated territory of South-West Africa.

It is possible that some may feel with Lord Bledisloe that at the present moment the needs of the situation will best be met by "the Government on the spot" rather than by any attempt to secure uniformity in a policy formulated by the Imperial Conference. Such a policy would have to apply to different races in different parts of the world, and this, it was maintained by Lord Dufferin in his reply on behalf of the Government, precluded the possibility of dealing with the varied conditions as a unitary whole. There is indeed much to be said for this point of view. Obviously the problem differs from one territory to another. In Canada and Australia, for example, it varies in essential features from the problem of West
Africa-the difference in the relative proportion of native and white alone places the latter in another category; but notwithstanding innumerable and important variations in detail, which necessitate elasticity in organization and machinery as between one part of the Empire and another, the inspiring principle may and should be the same, if trusteeship be adopted as the valid basis of relationship between ourselves and the less advanced races.

The eye of the practical administrator must necessarily be directed in affairs to the next step ; but even so, it is well to be sure of the general direction in which that step should lead. The state of affairs which has arisen in regard to the indigenous population of Nyasaland is largely the outcome of well-intentioned but misdirected effort in the past. The measures which are being taken to cope with the situation there, as reported by Mr. Ormsby-Gore in his annual survey of colonial affairs in the House of Commons on June 2, indicate the desirability of a unity of outlook in dealing with certain aspects of the native question in East and South Africa as a whole.

The aim of the Union of South Africa is to ensure the stability of a great and prosperous white man's country; but the native population outnumbers the white by something like four to one. Now, when Black Africa as a whole is awakening to an intense desire for development in one direction or another, South Africa is sitting on the safety valve. Over against the Union's policy of segregation stands as an alternative 'trusteeship'. But trusteeship is no more than a means to an end. Unless its function is interpreted constructively and in the light of scientific study of native institutions and the effect on them of the cultural impacts which must follow from the assumption of the obligation which trusteeship entails, premature inculcation of European ideals, social, ethical and economic, may prove no more beneficial and no less dangerous in the long run than segregation. It cannot be repeated too often, nor too insistently emphasized, that the time has now come when the ultimate aim of such measures as 'indirect rule' and 'trusteeship' should be defined in precise terms. In the formulation of this aim the prior necessity of anthropological study should not be ignored. The anthropologist alone is competent to determine and bring together the data upon which it will be possible to define the direction and rate of change least likely to bring disintegration and disaster in its train. 